\title{
HOURLY AND DAILY CHANGES ON AIRBORNE UREDINIOSPORES OF Phakopsora pachyrhizi
}

\author{
VARIAÇÃO HORÁRIA E DIÁRIA DE UREDINIOSPOROS DE Phakopsora pachyrhizi \\ $N O A R$
}

\author{
Marcello Arrais LIMA ${ }^{1}$; Luiz Eduardo Bassay BLUM² ; Carlos Hidemi UESUGI $^{3}$ \\ 1. Pesquisador colaborador, Dr. - Departamento de Fitopatologia, Universidade de Brasília, Brasília, DF, Brazil; 2. Professor Associado, \\ Ph.D. - Departamento de Fitopatologia, Universidade de Brasília, Brasília, DF, Brazil - luizblum@ unb.br; 3. Professor Associado, \\ Ph.D. - Departamento de Fitopatologia, Universidade de Brasília, Brasília, DF, Brazil
}

\begin{abstract}
The Asian rust (Phakopsora pachyrhizi) is one of the most destructive diseases of soybean in Brazil. Despite its importance, little is known about the airborne inoculum production dynamics of pathogen throughout the soybean cycle in Brazil. The objective of this study was to assess the temporal variation of air collected P. pachyrhizi urediniospores using a Burkard 7-day-spore-trap during 2006-2007 and 2007-2008, from November to March of each soybean (MSoy-8001) growing season. The disease severity was quantified on soybean planted in October 18, 2006 and in October 30, 2007. From November/06 through March/07 were collected over 175,000 urediniospores, and, over 131,000 from November/07 to March/08. In 06-07, most of the spores were collected from January 9, 2007 through February $1^{\text {st }}, 2007( \pm 3,000$ urediniospores day ${ }^{-1}$ ), and, in 07-08 most urediniospores was collected from February 8, 2008 throughout March 2, $2008\left( \pm 2,000\right.$ urediniospores day $\left.{ }^{-1}\right)$. The maximum amount of urediniospores collected in a single day in $06-07( \pm 15,000 ; 1 / 25 / 2007)$ was higher than in 07-08 $( \pm 12,000 ; 2 / 13 / 2008)$. In both soybean growing seasons most of the hourly urediniospores was collected from 10:00 am through 6:00 pm and the highest number from December to March, was at 3:00 pm ( $\pm 16,000$ in 06-07 and $\pm 14,000$ in 07-08). The disease started earlier in 2006-07 [38 days after planting (DAP)] than in 07-08 (58 DAP). The amount of collected airborne spores was positively correlated to disease severity, leaf wetness, and, precipitation along both soybean growing seasons. However, during a $24 \mathrm{~h}$-day evaluation, the major amount of hourly collected spores was negatively correlated to the leaf wetness and air relative humidity.
\end{abstract}

KEYWORDS: Airborne spore. 7-day-spore-trap. Burkard. Aerobiology.

\section{INTRODUCTION}

The Asian rust (Phakopsora pachyrhizi Syd. \& P. Syd.) of soybean (Glycine $\max$ L.) is a destructive foliar disease found in many soybeanproducing regions (YORINORI et al., 2005; ISARD et al., 2006; JARVIE 2009; ROSA et al., 2015; KELLY et al., 2015; MAUMARY et al., 2016; GODOY et al., 2016). Weather conditions influence directly in the cycle of the pathogen, which favors the development of rust epidemics on soybean (ISARD et al. 2005). Rainfall for 12-15 days is one of the main factors that explain the variations of disease severity in field condition (DEL PONTE et al., 2006; DUFAULT et al., 2010a). Marchetti et al. (1976), demonstrated that 6 hours of leaf wetness is the minimum time to ensure infection of soybean by the fungus. It is known that $18-26^{\circ} \mathrm{C}$ and leaf wetness duration determine the process of infection of urediniospores of $P$. pachyrhizi (ALVES et al., 2007).

The survey of airborne fungi spores by variable means has been done (LUO et al., 2007;
OLIVEIRA et al., 2009a; KUDO et al., 2011; DAS; GUPTA-BHATTACHARYA, 2012; ALMAGUER et al., 2013; RIEUX et al., 2014; AHER et al., 2015). The assessment of air inoculum can contribute to understanding the potential risk of epidemics of diseases during the plant cycle (WAKEHAM; KENNEDY, 2010; WEST; KIMBER 2015; IGARASHI et al., 2016). Airborne spores can be sampled in many ways; one of them is the stationary Burkard volumetric spore trap (WEST; KIMBER, 2015; WEST et al., 2017). This trap has been used for detection of fungi and pollen of plants (INCH et al., 2005; PEEL et al., 2014). However, studies concerning the quantification of the air dispersed urediniospores of P. pachyrhizi are limited (DEL PONTE et al., 2006; BARNES et al., 2009; ISARD et al., 2011; NASCIMENTO et al., 2012). Iamamoto (2008) using a spore trap in soybean field in central Brazil, stated that was possible to anticipate the chemical control of the soybean Asian rust in 14 to $15 \mathrm{~d}$. This author reported that air weekly collected spores from 100 to 600 could result in a rust outbreak. 
In some places, qualitative studies are made, and the most common airborne fungi spore assessed are anamorphic fungi and a much smaller amount are Uredinales-like spore (AHER et al., 2015). Other studies, beyond qualitative evaluations, make quantitative monthly assessments, and, sometimes, hourly collected spore quantifications (OLIVEIRA et al., 2009b; ALMAGUER et al., 2013). The highest concentrations of daily collected spores are around 9:00 am and 7:00 pm (GRANKE et al., 2014; ALMAGUER et al., 2013; FALL et al., 2016). Thus, the objective of this work was to quantify the hourly and daily collected airborne urediniospores of $P$. pachyrhizi for two growing soybean seasons.

\section{MATERIAL AND METHODS}

The experimental trials were conducted at the Experimental Station of Biology of the 'Universidade de Brasília', Brasília, DF, Brazil. Local coordinates are $15^{\circ} 44^{\prime} 07.59^{\prime \prime}$ South latitude
LIMA, M. A.; BLUM, L. E. B.; UESUGI, C. H.

and 47 $52^{\prime} 56.75^{\prime \prime}$ West longitude and an average altitude of $1009 \mathrm{~m}$. Before planting, the acidity of the soil was corrected with dolomitic limestone applications, following technical recommendations (EMBRAPA, 2006). The tillage was done with a disk plowing and twice levelling harrow in the area. The mineral fertilizer used was the 4-30-16 (NPK) following technical recommendations (EMBRAPA 2006). The seeds were planted manually to a depth of $4( \pm 1) \mathrm{cm}$. The population of soybean was 250,000 plants ha ${ }^{-1}\left(10\right.$ plants $\left.\mathrm{m}^{-1}\right)$, and the spacing between rows of $40 \mathrm{~cm}$. Seed were treated with thiamethoxan (Cruiser ${ }^{\mathrm{TM}}-35 \mathrm{~g}$ a.i. $100 \mathrm{~kg}^{-1}$ of seed.) + (metalaxyl+fludioxinil) (Maxim XL $\mathrm{XL}^{\mathrm{TM}}-1.0$ $+2.5 \mathrm{~g}$ a.i. $100 \mathrm{~kg}^{-1}$ of seed) and inoculated with $6 \mathrm{x}$ $10^{5} \mathrm{CFU}$ of Bradyrhizobium japonicum seed $^{-1}$. The planting of the first trial was done in 10/18/2006 and chemical treatments applied in 11/30 and 12/8/2006. The planting of the second trial was in 10/30/2007 and fungicides applied in 12/27/2007, 12/1 and 1/28/2008 (Table 1).

Table 1. Planting (MSoy-8001), first symptoms (pustules) appearance (\% of rusted leaf area), harvesting, soybean Asian-rust evaluations, and, fungicide $\left(0.5 \mathrm{~L} \mathrm{ha}^{-1}\right)$ treatment dates of field trials conducted in 2006-07 and 2007-08 at the University of Brasilia Experimental Station, Brasilia, DF, Brazil.

\begin{tabular}{llc}
\hline \multirow{2}{*}{ Information } & \multicolumn{2}{l}{ Soybean growing season } \\
\cline { 2 - 3 } & $2006-07$ & $2007-08$ \\
\hline Planting Date & $10 / 18 / 06$ & $10 / 30 / 07^{3}$ \\
Final stand (Plants / ha) & 250,000 & 250,000 \\
Symptoms appearance (SA) & $11 / 29 / 06$ & $12 / 26 / 07$ \\
Soybean growth stage in SA & $\mathrm{V} 3 / \mathrm{V} 4^{1}$ & $\mathrm{~V} 7 / \mathrm{V} 8$ \\
$\%$ of rusted leaf area in SA & $0.04 \%$ & $0.10 \%$ \\
Tetraconazole (Domark 100 CE) & $11 / 29 / 06(\mathrm{~V} 3 / \mathrm{V} 4)^{1}$ & $12 / 27 / 07(\mathrm{~V} 7 / \mathrm{V} 8)$ \\
Piraclostrobin+Epoxiconazole (Opera) & $10 / 1 / 07(\mathrm{R} 4 / \mathrm{R} 5)^{2}$ & $1 / 12 / 08(\mathrm{R} 1 / \mathrm{R} 2)$ \\
Rust evaluation & $11 / 22 / 06,11 / 29,12 / 6,12 / 18$ & $12 / 18 / 07,12 / 26$ \\
& $1 / 10 / 07,1 / 17,1 / 28$ & $1 / 5 / 08,1 / 11,1 / 17$, \\
Harvest & & $1 / 23,2 / 1,2 / 12,2 / 22$ \\
\end{tabular}

${ }^{1} \mathrm{Vn}=(\mathrm{n})$ number of trifoliolate leaves unrolled, $(\mathrm{n})+1$ number of nodes; ${ }^{2} \mathrm{R} 1=$ Beginning bloom - at least one flower is present on the main stem; R2 = Full bloom - flowers are found on any of the top two nodes; R4 = Full pod - pods are $2 \mathrm{~cm}$ long on one of the top four nodes; R5 = Beginning seed - seeds are $3 \mathrm{~mm}$ long on one of the top four nodes. ${ }^{3}$ month/day/year.

Respectively, in the first and second experiments were used the fungicides Tetraconazole $\left(\begin{array}{lll}\text { Domark } & 100 & \mathrm{CE}\end{array}\right.$ and Epoxiconazole+Pyraclostrobin $\left(\right.$ Opera $\left.{ }^{\circledR}\right)\left(0,5 \mathrm{~L} \mathrm{ha}^{-}\right.$ $\left.{ }^{1}\right)$. The application of fungicides was made with a backpack sprayer (20L - Kingfisher PS4020 20 Liter Backpack Sprayer - Yellow). Fungicide application started with the observation of first symptoms of disease (V3/V4 - 29/11/06; V7/V8 - 27/12/07) (Table 1). To evaluate the variation of urediniospores and the progress of the rust on the field, a two-year work has been made in a $600 \mathrm{~m}^{2}$ (30x20m) soybean (cv. MSoy-8001) planting area. This area was subdivided 24 plots of $25 \mathrm{~m}^{2}(5 \times 5 \mathrm{~m}$ plot $^{-1}$ ) for disease evaluation.

The Burkard 7-day-spore-trap (Burkard Scientific Ltd PO Box 55, Uxbridge, Middlesex, UB8 2RT, UK) was set in the central portion of the experimental area. The trap has been set on metal support, and the aspiration orifice $(2 \times 14 \mathrm{~mm})$ was positioned the $1.90 \mathrm{~m}$ in height from the ground. The air suction rate was $10 \mathrm{~L} / \mathrm{min}\left(14.4 \mathrm{~m}^{3} \mathrm{day}^{-1}\right)$. Inside the trap there was and aluminum drum rotating at a speed of $2 \mathrm{~mm} \mathrm{~h}^{-1}$, which contained a 
Hourly and daily...

clear plastic tape (Melinex, Burkard Ltd., Rickmansworth Hertfordshire, England) covered with a thin layer of silicon grease that was placed around it to capture the spores. The tape set to trap drum was replaced weekly.

Daily and hourly readings of the number of captured were taken every seven days, with seven slides for microscopy (one for each day of the week), with $48 \mathrm{~mm}$ tape piece per slide. In each 2$\mathrm{mm}$ tape (1 hour of collection) was counted the number of spores with an optical microscope (400x). Therefore, was quantified the number of spores collected per hour and day of the week and the daily concentration of urediniospores $\mathrm{m}^{-3}$ of air, as described by Lima et al. (2009).

The severity of the rust was estimated by the percentage of diseased leaf area (\% RLA) of each leaflet examined visually with a stereomicroscope. Three fully developed leaves from the inferior plantthird were randomly collected per plot in each evaluation date. The rust evaluations were made as follow: experiment $1-11 / 22,11 / 29,12 / 6$, 12/18/2006, 1/10, 1/17, 1/28/2007; experiment 2 $18 / 12,26 / 12 / 2007,1 / 5,1 / 11,1 / 17,1 / 23,2 / 1,2 / 12$, 2/22/2008.

In the center of the planting area was installed a weather station (Metos Compact, Pessel Instruments) with climatic sensors: air temperature $\left({ }^{\circ} \mathrm{C}\right)$ and relative humidity $(\%)$ (Temperature and Relative Humidity Probe Model A660610), which recorded the average, maximum and minimum hourly temperatures and humidity on the air; precipitation $(\mathrm{mm})$ (Tipping Bucket Rain Model M523CD); leaf wetness (minutes) (leaf wetness sensors Model IM521CD). The sensors were connected to the automatic data collection station. The data collection was done by transferring the information contained in the data platform for a laptop. Wind speed $\left(\mathrm{m} \mathrm{s}^{-1}\right)$ data were collected from a Meteorological Station $200 \mathrm{~m}$ far from the experiment. Correlation tests were carried out among the temporal collected urediniospores, disease severity, and climatic variables, using the Spearman rank correlation coefficient. The number of spores from a day was correlated to the percentage of damaged leaf area climatic and to the climatic variables the same day, as well as to the values taken up to 10 days before the rust evaluation.

\section{RESULTS}

Airborne urediniospores of $P$. pachyrhizi was collected mainly from 60 to 110 days after
LIMA, M. A.; BLUM, L. E. B.; UESUGI, C. H.

planting (DAP) in both growing seasons (Figure 1A). However, spores were collected in both growing seasons since 30 DAP. From November/06 through March/07 were collected over 175,000 urediniospores season ${ }^{-1}$, and, over 131,000 from November/07 to March/08. In 2006-07, most of the spore were collected from January 9, 2007 through February $1^{\text {st }}, 2007\left( \pm 3,000\right.$ urediniospores day $^{-1}=$ 208 urediniospores $\mathrm{m}^{-3}$ ), and, in 2007-08 most urediniospores was collected from February 8, 2008 throughout March 2, $2008( \pm 2,000$ urediniospores day $^{-1}=139$ urediniospores $\left.\mathrm{m}^{-3}\right)$. The maximum amount of urediniospores collected in a single day in 2006-07 $\left(14,948=1,038\right.$ urediniospores $\mathrm{m}^{-3}$ January 25, 2007) was higher than in 2007-08 $\left( \pm 11,889=826\right.$ urediniospores $\mathrm{m}^{-3}$; February 13 , 2008) (Figures 1A; 2D). In 2006-07 from 70 to 110 DAP there were 9 spore peaks $(\geq 2,000$ urediniospores day ${ }^{-1}=139$ urediniospores $\mathrm{m}^{-3}$ ), with an average of 5 days between them (Figure 1A). In the same period, in 2007-08, there were 5 spore peaks, with an average of 8 days between them. Most of the spores were collected until 100 DAP in the first season and 100 DAP in the second (Figure 1B). The disease started earlier in 2006/07 [38 days after planting (DAP)] than in 2007-08 (58 DAP). In 2006-07 the disease reached $\sim 45 \%$ (\%RLA) and in 2007-08 20\%. After 110 DAP the \%RLA was over 50 and $\sim 30$ in 2006-07 and 2007-08, respectively (Figure 1C).

Rust favorable (10-day period with leaf wetness $\geq 6$ hours day $^{-1}$ ) amount of leaf wetness occurred from 60 to 85 days in 2006-07 and from 85 to 110 in 2007-08 soybean growing season (Figure 1D). Most favorable relative humidity (\%) and minutes $\mathrm{h}^{-1}$ of leaf wetness, occurred from 70 to 85 DAP in 2006-07 and from 90 to 110 DAP (Figure $2 \mathrm{~A}$; B). From, 70 to 110 DAP, the average temperature in $2006-07$ was higher $\left(\sim 21^{\circ} \mathrm{C}\right)$ than the one $\left(20^{\circ} \mathrm{C}\right)$ in $2007-08$ (Figure $2 \mathrm{C}$ ).

In both soybean growing seasons most of the hourly urediniospores was collected from 10:00 am through 6:00 pm and the highest number from December to March, was at 3:00 pm $( \pm 16,000$ in $2006 / 07$ and $\pm 14,000$ in 2007/08) (Figure 3A). Numbers of hourly collected urediniospores were higher as lower were the hourly average of relative humidity (Figure 3B) and minutes of leaf wetness / hour (Figure 3C). The collected hourly airborne spore was higher as higher was the hour variation of temperature (Figure 3D). 

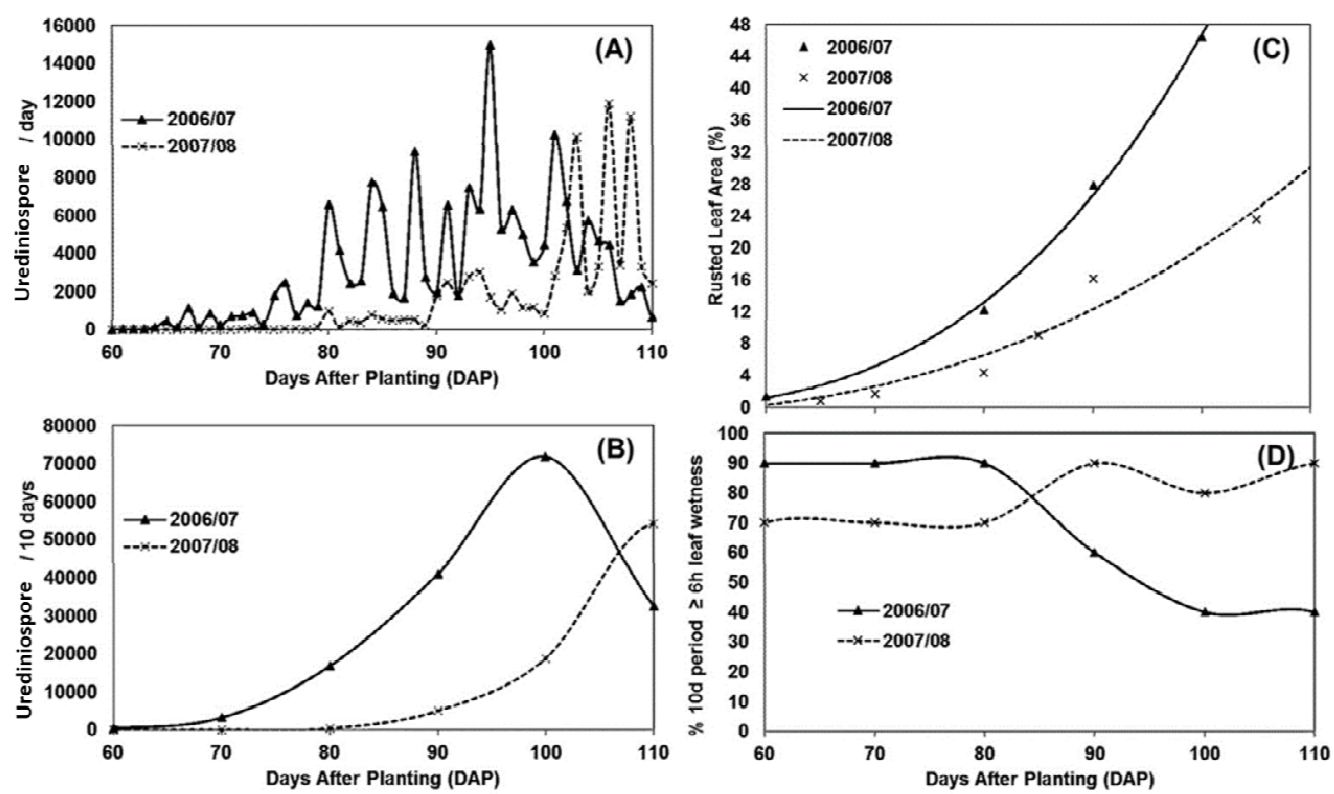

Figure 1. Total of urediniospores of Phakopsora pachyrhizi collected daily (A) and accumulated every 10 days (B) from December 2006 to March 2007 (black line) and from December 2007 to March 2008 (dotted line). (C) Asian Soybean Rust severity (\% of rusted leaf area) progress in two growing seasons (2006/2007; 2007/2008) on soybean cultivar MSoy-8001. (D) Percentage of a 10-day period with leaf wetness $\geq 6$ hours day ${ }^{-1}$. $\left[14,400\right.$ urediniospores day ${ }^{-1}=1,000$ urediniospores $\left.\mathrm{m}^{-3}\right]$.
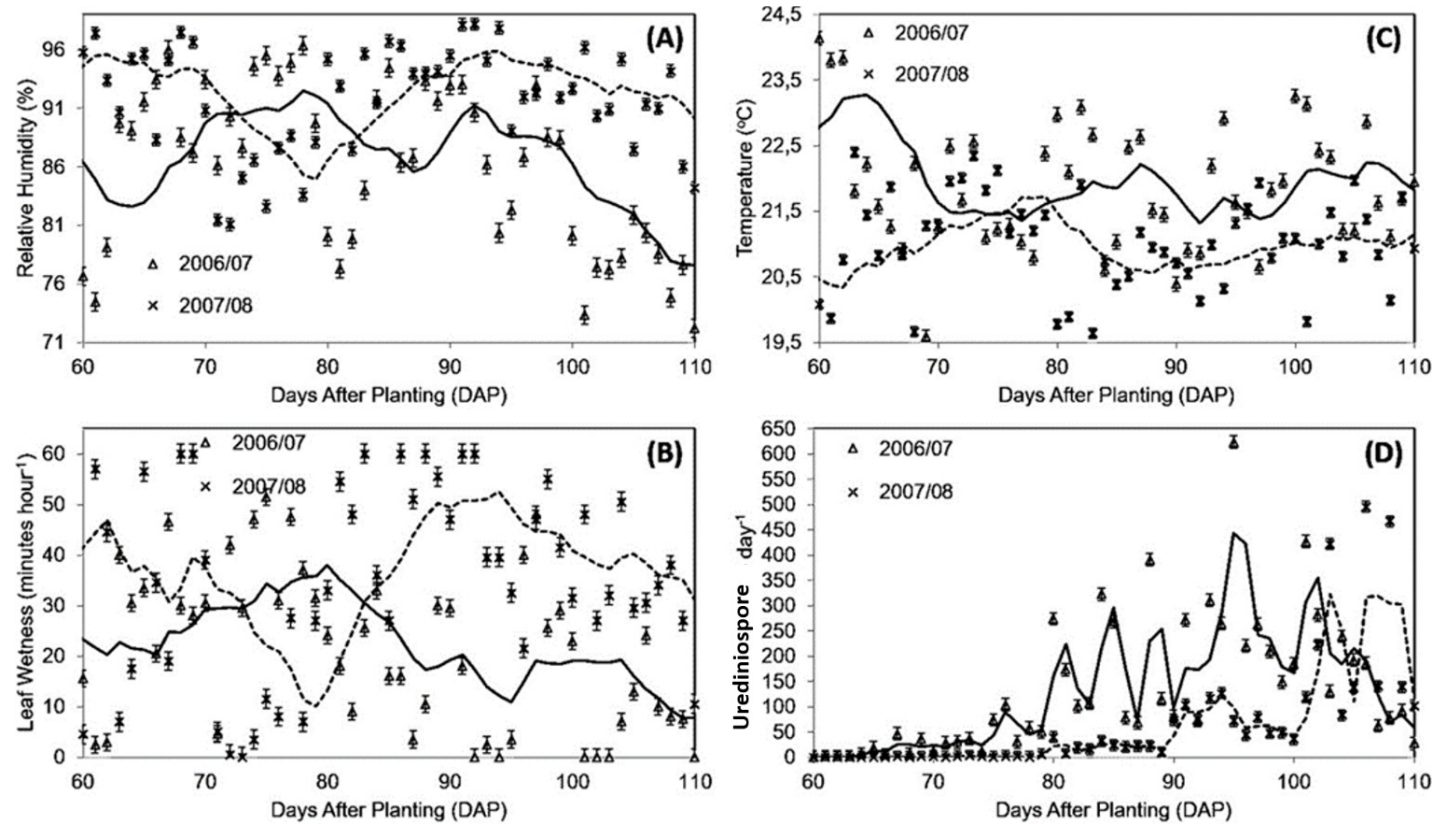

Figure 2. (A) Moving average of relative humidity (\%) from 12/2006 to 3/2007 (black line) and from 12/2007 to 3/2008 (dotted line). (B) Moving average of leaf wetness (minutes / hour) from 12/2006 to 3/2007 (black) and from 12/2007 to 12/2008 (dotted). (C) Moving average of temperature $\left({ }^{\circ} \mathrm{C}\right.$ ) from 12/2006 to $3 / 2007$ (black) and from 12/2007 to 3/2008 (dotted). (D) Daly moving average of the number of urediniospores of Phakopsora pachyrhizi collected from 12/2006 to 3/2007 (black) and from 12/2007 to $3 / 2008$ (dotted). 

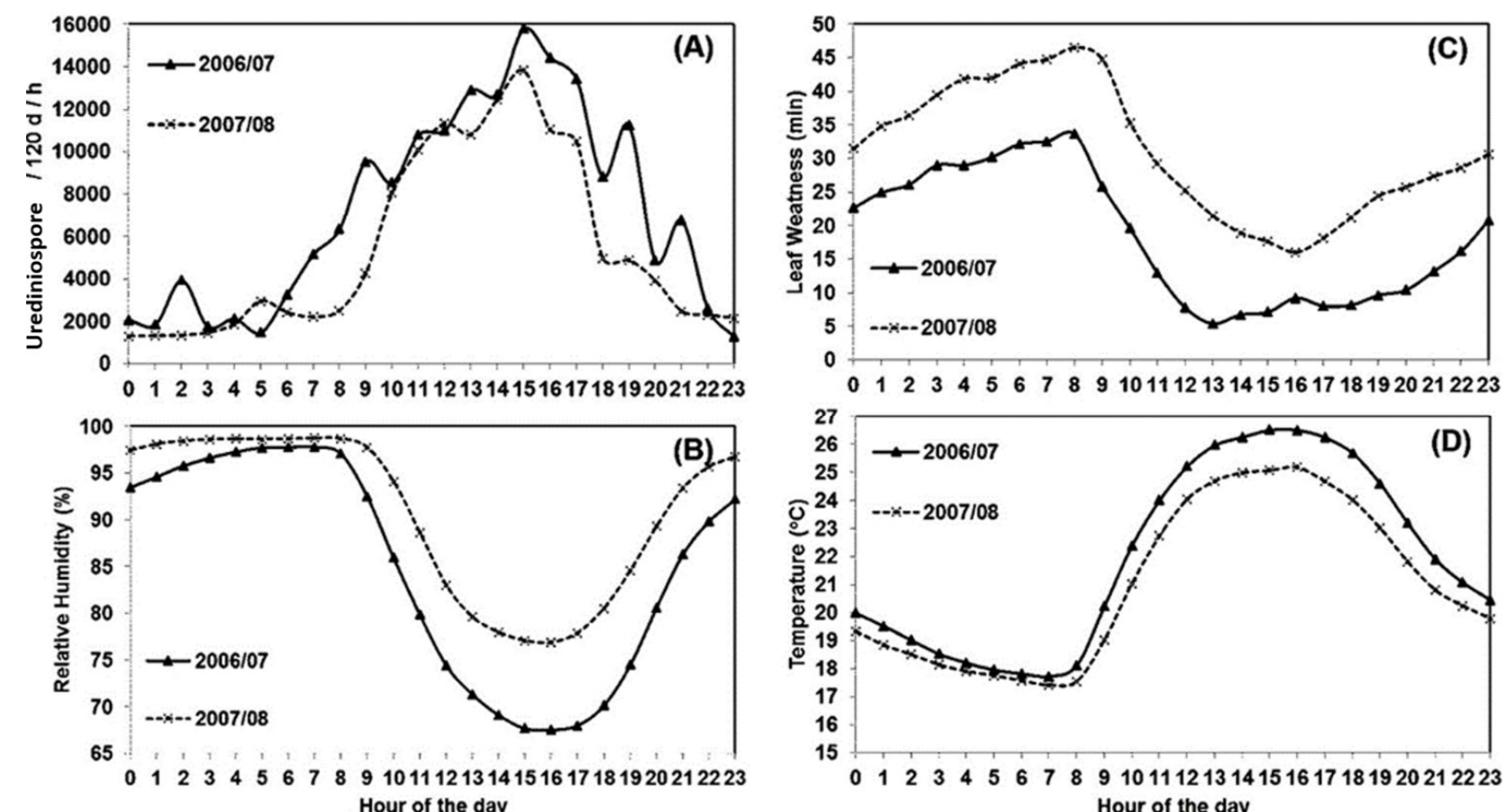

Figure 3. (A) Total of the hourly collected urediniospores of Phakopsora pachyrhizi from 12/2006 to 3/2007 (black line) and from 12/2007 to 3/2008 (dotted line). (B) Hourly average of the relative humidity (\%) from 12/2006 to 3/2007 (black line) and from 12/2007 to 3/2008 (dotted line). (C) Hourly average of the leaf wetness (min) from 12/2006 to 3/2007 (black line) and from 12/2007 to 3/2008 (dotted line). (D) Hourly average of the temperature $\left({ }^{\circ} \mathrm{C}\right.$ ) from 12/2006 to 3/2007 (black line) and from $12 / 2007$ to $3 / 2008$ (dotted line). [14,400 urediniospores day ${ }^{-1}=1,000$ urediniospores $\mathrm{m}^{-3}$ ].

The amount of collected airborne spores was positively correlated [Sperman's $(\rho)$ correlation coefficient] to disease severity $(0.82 \sim 0.83, \mathrm{p} \leq$ $0.05)$, leaf wetness $(0.38 \sim 0.45 ; \mathrm{p} \leq 0.01)$, and, precipitation $(0.26 \sim 0.30 ; \mathrm{p} \leq 0.01)$ along both soybean growing seasons (Table 2). However, during a 24h-day evaluation, the major amount of hourly collected spores was negatively correlated to the leaf wetness $(-0.65 \sim-0.73 ; \mathrm{p} \leq 0.01)$ and relative humidity $(-0.78 \sim-0.80 ; \mathrm{p} \leq 0.01)$ (Table 3 ; Figure 3A-D). The hourly collected spores were negatively correlated to hourly-precipitation, however, no significant correlation was established (Table 3 ).

Table 2. Spearman's ( $\rho$ ) correlation coefficient among the number of daily collected urediniospores (Ured), rust severity (Rse), and daily evaluated climatic variables [Temperature (T), relative air humidity $(\mathrm{RH})$, leaf wetness (LW) and precipitation (Ppt)].

\begin{tabular}{|c|c|c|c|c|c|c|c|c|c|}
\hline \multirow{2}{*}{ Variable } & \multicolumn{3}{|c|}{ Temperature } & \multicolumn{3}{|c|}{ Relative Humidity } & \multirow{2}{*}{ LW } & \multirow{2}{*}{$\mathrm{Ppt}$} & \multirow{2}{*}{ Rse } \\
\hline & Max & Min & Avg & Max & Min & Avg & & & \\
\hline Ured 06-07 & Ns & $0.37 * *$ & $0.25 * *$ & $0.19 *$ & $0.30 * *$ & $0.31 * *$ & $0.45 * *$ & $0.26 * *$ & $0.82 *$ \\
\hline Ured 07-08 & Ns & $0.18 *$ & Ns & $0.40 * *$ & $0.34 * *$ & $0.39 * *$ & $0.38 * *$ & $0.30 * *$ & $0.83 *$ \\
\hline Rse 06-07 & Ns & Ns & Ns & Ns & Ns & $0.87 *$ & $0.90 *$ & $0.83 *$ & - \\
\hline Rse $07-08$ & $0.66^{*}$ & ns & $-0.77 * *$ & Ns & Ns & $0.65^{*}$ & $0.63 *$ & Ns & - \\
\hline
\end{tabular}

$\mathrm{Ns}=$ not significant; * significant $(\mathrm{p} \leq 0.05) ; * *$ significant $(\mathrm{p} \leq 0.01) ;$ Max $=$ maximum; Min $=$ minimum; Avg $=$ average. For analyses was considered the last 9 days (lag period) before disease evaluation.

Table 3. Spearman's $(\rho)$ correlation coefficient among the number of hourly collected urediniospores (Ured) and hourly evaluated climatic variables [Temperature $(\mathrm{T})$, relative air humidity $(\mathrm{RH})$, leaf wetness (LW) and precipitation (Ppt)].

\begin{tabular}{lllll}
\hline Variable & $\mathrm{T}$ & $\mathrm{RH}$ & $\mathrm{LW}$ & $\mathrm{Ppt}$ \\
\hline Ured 2006-07 & $0.80^{* *}$ & $-0.80^{* *}$ & $-0.73^{* *}$ & $\mathrm{Ns}$ \\
Ured 2007-08 & $0.79^{* *}$ & $-0.78^{* *}$ & $-0.65^{* *}$ & $\mathrm{Ns}$ \\
\hline
\end{tabular}

* Significant ( $\mathrm{p} \leq 0.05) ; * *$ significant $(\mathrm{p} \leq 0.01)$; Ns = not significant; For analyses was considered the hourly average of 90 days $(41-$ 130 DAP). 


\section{DISCUSSION}

Aerial spores of $P$. pachyrhizi might have a significant role in this fungal spread and distribution (HARTMAN; HAUDENSHIELD, 2009). The number of collected airborne spores varies from place to place and due to the hour of the day (OLIVEIRA et al., 2009a; 2009b). Most of these seasonal variations are associated to meteorological variables. Isard et al. (2005) has affirmed the role of environmental factors such as daylight, temperature, and humidity may affect the timing of spore release. Nascimento et al. (2012) stated that the number of airborne spores of $P$. pachyrhizi was related to the presence of soybean field crop, and there were positive correlations among the number of urediniospores, cumulative rainfall, disease intensity and favorable days for Asian rust (SAR). In addition, those authors defined the favorability to epidemic of SAR was associated to $18-26^{\circ} \mathrm{C}$ and 90 $100 \%$ relative humidity.

In some studies, the highest number of airborne spores occurs from 9:00 am to 1:00 pm (Granke \& Hausbeck., 2010). Faal et al. (2016) reported in Canada that most of airborne spores of Bremia lactucae were hourly collected from 11:00 am to 1:00 pm. Almager et al. (2013), in Havana, Cuba, reported that the most common taxa peaking at 11:00 am to 12:00 pm were Cladosporium, Bipolaris, Nigrospora, Periconia, Alternaria, Uredinales-type, Pseudocercospora, Chaetomium, Curvularia, Monodictys, Stemphyllium and Pithomyces. Blum \& Dianese (2001) reported that most of the Puccinia psidii urediniospores were collected between 10:00 am to 1:00 pm, in Brasilia, DF, Brazil, during a survey made in 1988. In the present work, in both soybean growing seasons most of the hourly urediniospores was collected from 10:00 am through 6:00 $\mathrm{pm}$ and the highest number was at 3:00 pm (Figure 3A).

However, in a study made in Manitoba, Canada, monitoring airborne-ascospores of Gibberella zeae, the maximum amount was collected at 9:00 pm (INCH et al., 2005). Correia \& Costa (2005), noted that the period of spore release Lasiodiplodia theobromae occurred during the hours of 6:00 am to 10:00 am. Schuh (1993) reported that Cercospora kikuchii released spores between 4:00 am and 8:00 am and between 6:00 pm and 9:00 pm. These, daily and hourly variations of collected spores are affected by environmental and type of the fungal spore (OLIVEIRA et al., 2009a; GRANKE et al., 2014). Fitt et al. (1989), informed that the release of spores that are scattered in dry air shows a diurnal periodicity, often, the spores are collected around 12:00 pm when the wind speed is higher, the temperature is higher, and the relative humidity is lower. Conversely, Correia \& Costa (2005) observed that, with rain precipitations above $80 \mathrm{~mm}$, the conidia of $L$. theobromae in coconut tree began to be precipitated from the air, and consequently resulted in the decrease of spores captured.

From 9:00 pm to 8:00 am, few spores of $P$. pachyrhizi were collected; this fact might be associated to the moisture on leaf (BECK et al., 2006). Therefore, the spore release would not start before leaf wetness dried out (BECK et al., 2006). Boudrot et al. (2016) reported that a high frequency of Hemileia vastatrix urediniospores capture occurred from 7:00 am to 7:00pm, and very little from 8:00 pm to 6:00 am. These authors also showed a strong effect of the hour of the day on the dispersal of urediniospores, and, this diurnal pattern of pathogen dispersal where the highest dispersal occurred late in the morning and in the early afternoon was linked to the decrease in relative humidity and the highest recorded wind speed. Vuorinen \& Helander (1995) found that airborne collected urediniospores of Melampsoridium betulinum showed a circadian variation with a peak was observed from12:00 am to 4:00 pm. As in the present study, these authors also found that a high wind speed (Figure 4) significantly increased airborne urediniospores concentration; likewise, temperature affected the spore concentration positively.

The most favorable conditions to SAR epidemics reported are: (a) minimum leaf wetness (LW) of $6 \mathrm{~h}$ per day; (b) optimum LW of 12-14h per day; (c) optimum temperature for spore germination of $18-26^{\circ} \mathrm{C}$; (d) optimum minimum temperature from 20 to $23^{\circ} \mathrm{C}$; (e) optimum maximum temperature inferior to $28^{\circ} \mathrm{C}$; (f) optimum minimum RH from 75 to $80 \%$; (g) constant daily rain for 12 15 days (ALVES et al., 2007; BLUM et al., 2015; DEL PONTE et al., 2006; BONDE et al., 2007; DEL PONTE; ESKER, 2008; BONDE et al., 2013; DANELLI; REIS, 2016; DUFAULT et al., 2010b; ISARD et al., 2005; MARCHETTI et al., 1976; MELCHING et al., 1979; MELCHING et al., 1989; NASCIMENTO et al., 2012; YANEZ-LOPEZ et al., 2015). Under these conditions, from the urediniospores germination and hyphae penetration to new urediniospores formation, it takes 7-10 days (GARCÉS-FIALLOS, 2011). In this study, most favorable conditions (temperature, moisture, leaf wetness, rainfall) occurred in 2006-07 earlier than in 2007-08. Possibly, it is the main reason for higher levels of airborne spores and disease severity in 
2006-07 than in 2007-08. Young et al. (2011) stated that precipitation was the main factor affecting SAR progress, where disease increased rapidly after rain occurrences.

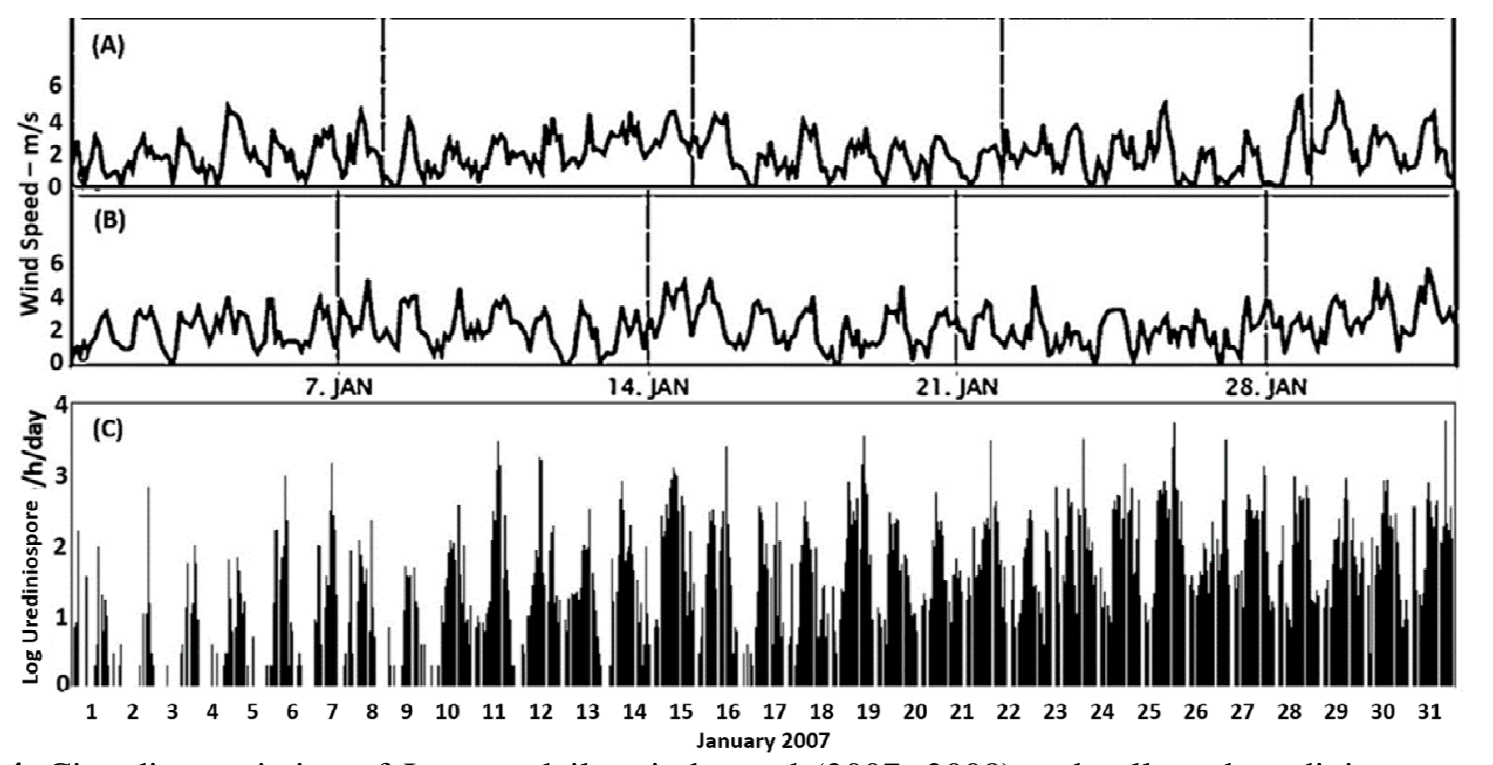

Figure 4. Circadian variation of January daily wind speed (2007; 2008) and collected urediniospores (2007). (A) Wind speed $\left(\mathrm{m} \mathrm{s}^{-1}\right)$ in January 2007, and (B) January 2008. (C) Urediniospores of Phakopsora pachyrhizi collected hourly and daily during January 2007.

\section{CONCLUSIONS}

The maximum amount of urediniospores collected in a single was around 15,000 in $1 / 25 / 2007$ ) and, around 12,000 in 2/13/2008.

In both soybean growing seasons most of the hourly urediniospores was collected from 10:00 am through 6:00 pm.

The highest amount of airborne-collectedurediniospores from December to March, was at 3:00 pm.

The disease started earlier in 2006-07 [38 days after planting (DAP)] than in 07-08 (58 DAP).

The amount of airborne spores was positively correlated to disease severity, leaf wetness, and, precipitation along both soybean growing seasons.
During a $24 \mathrm{~h}$-day evaluation, the major amount of hourly collected spores was negatively correlated to the leaf wetness and air relative humidity.

\section{ACKNOWLEDGEMENTS}

The authors acknowledge the Higher Education Personnel Coordination (CAPES) and the National Council for Scientific and Technological Development (CNPq) for a PhD scholarship to the first author and a productivity grant to the second, and the Foundation for Research Support of the Federal District (FAP-DF) for partly financing the research.

RESUMO: A ferrugem asiática (Phakopsora pachyrhizi) é uma das doenças mais destrutivas de soja no Brasil. Apesar de sua importância, pouco é conhecido sobre a dinâmica de distribuição de inóculo no ar do patógeno em todo o ciclo da soja no Brasil. O objetivo deste estudo foi avaliar a variação temporal de urediniósporos de $P$. pachyrhizi coletados do ar com uma armadilha de esporos Burkard de 7 dias de captura em 2006-2007 e 2007-2008, durante o cultivo da soja (cv. MSoy-8001) entre novembro e março. A severidade da doença foi quantificada em soja plantada em 18 de outubro de 2006 e em 30 de outubro de 2007. De novembro/06 até março/07 foram coletados mais de 175.000 urediniósporos, e, mais de 131.000 de novembro/07 a março/08. Em $06 / 07$, a maioria dos esporos foram coletada de 9 de janeiro de 2007 a $1^{\circ}$. de fevereiro de 2007 ( \pm 3.000 urediniósporos $\left.\mathrm{dia}^{-1}\right)$, e, em 07-08 a maioria dos urediniósporos foi coletada entre 8 de fevereiro de 2008 e 2 de março de $2008\left( \pm 2,000\right.$ uredosporo dia $\left.{ }^{-1}\right)$. A quantidade máxima de urediniósporos coletados em um único dia em 06-07 $( \pm 15,000 ; 25 / 1 / 2007)$ foi superior a 07-08 $( \pm 12,000 ; 13 / 2 / 2008)$. Em ambas as safras de soja a maioria dos urediniósporos em cada hora foi coletado entre 10:00 e 18:00 de 
dezembro a março e o maior número foi às 15:00 ( $\pm 16,000$ em 06-07 e $\pm 14,000$ em 07-08). A doença iniciou mais cedo em 2006-07 [38 dias após o plantio (DAP)] do que em 07-08 (58 DAP). A quantidade de esporos no ar coletados correlacionou-se positivamente a severidade da doença, umidade foliar, e precipitação ao longo de ambos os ciclos de soja. No entanto, durante a avaliação diária, a quantidade de esporos coletados por hora foi negativamente correlacionada com umidade foliar e a umidade relativa do ar.

PALAVRAS-CHAVE: Esporos no ar. Armadilha de esporos do ar. Burkard. Aerobiologia.

\section{REFERENCES}

AHER, S. K.; DHAWALE, V. P.; BAVISKAR, P. S. Qualitative Assessment of airborne deuterospores over pomegranate (Punica granatum L.) field. International Journal of Life Sciences, Maharashtra, Special Issue A3, p.18-20. 2015.

ALMAGUER, M.; AIRA, M. J.; RODRÍGUEZ-RAJO, F. J.; ROJAS, T. I. Study of airborne fungus spores by viable and non-viable methods in Havana, Cuba. Grana, Stockholm, v.52, n. 4, p.289-298. 2013. https://doi.org/10.1080/00173134.2013.829869

ALVES, M. C.; POZZA, E. A.; FERREIRA, J. B.; ARAÚJO, D. V.; COSTA, J. C. B.; DEUNER, C. C.; MUNIZ, M. F. S.; ZAMBENEDETTI, E. B.; MACHADO, J. C. Intensidade da ferrugem asiática (Phakopsora pachyrhizi H. Sydow \& P. Sydow) da soja [Glycine max (L.) Merr.] nas cultivares Conquista, Savana e Suprema sob diferentes temperaturas e períodos de molhamento foliar. Summa Phytopathologica, Botucatu, v. 33, n. 3, p. 239-244. 2007. https://doi.org/10.1590/S0100-54052007000300005

BARNES, C. W.; SZABO, L. J.; BOWERSOX, V. C. Identifying and quantifying Phakopsora pachyrhizi spores in rain. Phytopathology, St. Paul, v. 99, n. 4, p. 328-338. 2009.

BECK, L. F.; MILES, M. R.; STEILAGE, T. A.; HARTMANN, G. L. Urediniospore release and escape from rust-infected soybean fields. In: National Soybean Rust Symposium, St. Louis, 2006. Proceedings. St. Paul: APS, 2006. http://www.plantmanagementnetwork.org/ infocenter/topic/soybeanrust/2006/posters/38.asp. Accessed in 23 April 2017.

BLUM, M. M. C.; REIS, E. M.; FRANCIEI, T.V.; CARLINI, R. In vitro effect of substrate, temperature and photoperiod on Phakopsora pachyrhizi urediniospore germination and germ tube growth. Summa Phytopathologica, Botucatu, v. 41, n. 2, p. 101-106. 2015.

BLUM, L. E. B.; DIANESE, J. C. Padrões de liberação de urediniósporos e desenvolvimento da ferrugem do jambeiro. Pesquisa Agropecuária Brasileira, Brasília, v. 36, n. 6, p. 845-850. 2001. https://doi.org/10.1590/S0100-204X2001000600001

BONDE, M.R.; BERNER, D. K.; NESTER, S. E.; FREDERICK, R. D. Effects of temperature on urediniospore germination, germ tube growth, and initiation of infection in soybean by Phakopsora isolates. Phytopathology, St. Paul, v. 97, n. 8, p. 997-1003. 2007.

BONDE, M. R.; NESTER, S. E.; BERNER, D. K. Effects of frequency of "extreme" temperature highs on development of soybean rust. Phytopathology, St. Paul, v. 103, n. 7, p. 708-716. 2013.

BOUDROT, A.; J. PICO; MERLE, I.; GRANADOS, E.; VILCHEZ, S.; TIXIER, P.; VIRGINIO FILHO, E. M.; CASANOVES, F.; TAPIA, A.; ALLINNE, C.; RICE, R. A.; AVELINO, J. Shade effects on the dispersal of airborne Hemileia vastatrix uredospore. Phytopathology, St. Paul, v. 106, n. 6, p. 572-580. 2016.

CORREIA, M. S.; COSTA, J. L. S. Dispersão anemófila do fungo Lasiodiplodia theobromae em plantações de coqueiro. Fitopatologia Brasileira, Fortaleza, v. 30, n. 2, 150-154. 2005. https://doi.org/10.1590/S010041582005000200008 
DANELLI, A. L. D.; REIS, E. M. Quantification of incubation, latent and infection periods of Phakopsora pachyrhizi in soybean, according to chronological time and degree-days. Summa Phytopathologica, Botucatu, v. 42, n. 1, p. 11-17. 2016.

DAS, S.; GUPTA-BHATTACHARYA, S. Monitoring and assessment of airborne fungi in Kolkata, India, by viable and non-viable air sampling methods. Environmental Monitoring and Assessment, Amsterdam, v. 184, p. 4671-4684. 2012. https://doi.org/10.1007/s10661-011-2294-1

DEL PONTE, E. M.; GODOY, C. V.; LI, X.; YANG, X. B. Predicting severity of Asian soybean rust epidemics with empirical rainfall models. Phytopathology, St. Paul, v. 96, n. 7, p. 797-803. 2006

DEL PONTE, E. M.; ESKER, P. D. Meteorological factors and Asian soybean rust epidemics: a systems approach and implications for risk assessment. Scientia Agricola, Piracicaba, v. 65, n. special, p. 88-97. 2008.

DUFAULT, N. S.; ISARD, S. A.; MAROIS, J. J.; WRIGHT, D. L. The influence of rainfall intensity and soybean plant row spacing on the vertical distribution of wet deposited Phakopsora pachyrhizi urediniospores. Canadian Journal of Phytopathology, Philadelphia, v. 32, n. 2, p. 162-169. 2010a.

DUFAULT, N. S.; ISARD, S. A.; MAROIS, J. J.; WRIGHT, D. L. Removal of wet deposited Phakopsora pachyrhizi urediniospores from soybean leaves by subsequent rainfall. Plant Disease, St. Paul, v. 94, n.11, p. 1336-1340. 2010b.

EMBRAPA - Empresa Brasileira de Pesquisa Agropecuária. Tecnologias de produção de soja região central do Brasil. Embrapa Soja, Londrina-PR. 2006. 220p.

FALL, M. L.; VAN DER HEYDEN, H.; CARISSE, O. A. Quantitative dynamic simulation of Bremia lactucae airborne conidia concentration above a lettuce canopy. Plos One, San Francisco, v. 11, n. 3, e0144573. 2016. https://doi.org/10.1371/journal.pone.0144573

FITT, B. D. L.; MCCARTNEY, H. A.; WALKLATE, P. J. The role of rain in dispersal pathogen inoculum. Annual Review of Phytopathology, Palo Alto, v. 27, p. 241-270. 1989.

https://doi.org/10.1146/annurev.py.27.090189.001325

GARCÉS-FIALLOS, F. R. A ferrugem asiática da soja causador por Phakopsora pachyrhizi Sydow e Sydow. Ciência Y Tecnologia, Quito, v. 2, n. 4, p. 45-60. 2011.

GODOY, C. V.; SEIXAS, C. D. S.; SOARES, R. M.; MARCELINO-GUIMARÃES, F. C.; MEYER, M. C.; COSTAMILAN, L. M. Asian soybean rust in Brazil: past, present, and future. Pesquisa agropecuária brasileira, Brasília, v. 51, n. 5, p. 407-421. 2016.

GRANKE, L. L.; HAUSBECK, M. K. Influence of environment on airborne spore concentrations and severity of Asparagus purple spot. Plant Disease, St. Paul, v.94, n. 7, p. 843-850. 2010.

GRANKE, L. L.; MORRICE, J. J.; HAUSBECK, M. K. Relationships between airborne Pseudoperonospora cubensis sporangia, environmental conditions, and cucumber downy mildew severity. Plant Disease, St. Paul, v. 98, n. 5, p. 674-681. 2014.

HARTMAN, G. L.; HAUDENSHIELD, J. S. Movement of Phakopsora pachyrhizi (soybean rust) spores by non-conventional means. European Journal of Plant Pathology, Dordrecht, v. 123, p. 225-228. 2009. https://doi.org/10.1007/s10658-008-9352-8

IAMAMOTO, M. M. Curva populacional de Phakopsora pachyrhizi, agente causal da ferrugem asiática da soja, através de armadilha caça-esporos na safra 2007-08, em Costa Rica, MS. XXX Reunião de Pesquisa de Soja da Região Central do Brasil. P. 145-146. 2008 
IGARASHI, W. T.; FRANÇA, J. A.; AGUIAR E SILVA, M. A.; IGARASHI, S.; SAAB, O. J. G. A. Application of prediction models of asian soybean rust in two crop seasons, in Londrina, PR. Semina: Ciências Agrárias, Londrina, v. 37, n. 5, p. 2881-2890. 2016. https://doi.org/10.5433/16790359.2016v37n5p2881

INCH, S.; FERNANDO, W. G. D.; GILBERT, G. Seasonal and daily variation in the airborne concentration of Gibberella zeae (Schw.) Petch spores in Manitoba. Canadian Journal of Phytopathology, Philadelphia, v. 27, 357-363. 2005.

ISARD, S. A.; BARNES, C. W.; HAMBLETON, S.; ARIATTI, A.; RUSSO, J. M.; TENUTA, A.; GAY, D. A.; SZABO, L. J. Predicting soybean rust incursions into the North American continental interior using crop monitoring, spore trapping, and aerobiological modeling. Plant Disease, St. Paul, v. 95, n. 11, p. 1346-1357. 2011. https://doi.org/10.1641/0006-3568(2005)055[0851:POTAPF]2.0.CO;2

ISARD, S. A.; GAGE, S. H.; COMTOIS, P.; RUSSO, J. M. Principles of the atmospheric pathway for invasive species applied to soybean rust. Bioscience, Washington, v. 55, n. 10, p. 851-862. 2005.

ISARD, S. A.; DUFAULT, N. S.; MILES, M. R.; HARTMAN, G. L.; RUSSO, J. M.; DE WOLF, E. D.; MOREL, W. The effect of solar irradiance on the mortality of Phakopsora pachyrhizi urediniospores. Plant Disease, St. Paul, v. 90, n. 7, p. 941-945. 2006.

JARVIE J. A. A review of soybean rust from a South African perspective. South African Journal of Science, Lynnwood Ridge, v. 105, n. 3-4, p. 103-108. 2009.

KELLY, H. Y.; DUFAULT, N. S.; WALKER, D. R.; ISARD, S. A.; SCHNEIDER, R. W.; GIESLER, L. J.; WRIGHT, D. L.; MAROIS, J. J.; HARTMAN, G. L. From select agent to an established pathogen: the response to Phakopsora pachyrhizi (soybean rust) in North America. Phytopathology, St. Paul, 105, n. 7, p. 905-916. 2015.

KUDO, A. S.; BLUM, L. E. B.; LIMA, M. A. Aerobiologia de Cercospora kikuchii. Ciência Rural, Santa Maria, v. 41, n. 10, p. 1682-1688. 2011. https://doi.org/10.1590/S0103-84782011005000128

LIMA, M. A.; MAFFIA, L. A.; BARRETO, R. W.; MIZUBUTI, E. S. G. Phytophthora infestans in a subtropical region: survival on tomato debris, temporal dynamics of airborne sporangia and alternative hosts. Plant Pathology, Oxford, v. 58, n. 1, p. 87-99. 2009. https://doi.org/10.1111/j.1365-3059.2008.01951.x

LUO, Y.; MA, Z.; REYES, H. C.; MORGAN, D.; MICHAILIDES, T. J. (). Quantification of airborne spores of Monilinia fructicola in stone fruit orchards of California using real-time PCR. European Journal of Plant Pathology, Dordrecht, v. 118, n. 2, p.145-154. 2007. https://doi.org/10.1007/s10658-007-9124-x

MARCHETTI, M. A., MELCHING, J. S. \& BROMFIELD, K. R. The effects of temperature and dew period on germination and infection by urediniosporess of Phakopsora pachyrhizi. Phythopatology, St. Paul, v.66, n. 4, p. 461- 463. 1976.

MAUMARY, R. L.; PIOLI, R. N.; AMSLER, A.; IVANCOVICH, A. Germinación e infección de Phakopsora pachyrhizi en ambiente simulado del área central de Santa Fe, Argentina. Chilean Journal of Agricultural \& Animal Sciences, Chillán, v. 32, n. 3, p. 173-183. 2016.

MELCHING, J. S.; BROMFIELD, K. R.; KINGSOLVER, C. H. Infection, colonization and urediniospores production on Wayne soybean by four cultures of Phakopsora pachyrhizi, the cause of soybean rust.

Phytopathology, St. Paul, v. 69, n. 12, p. 1262-1265. 1979

MELCHING, J. S.; DOWLER, W. M.; KOOGLE, D. L.; ROYER, M. H. Effects of duration, frequency, and temperature on leaf wetness periods on soybean rust. Plant Disease, St. Paul, v. 73, n. 2, p. 117-122. 1989. 
NASCIMENTO, J. F.; VIDA, J. B.; TESSMANN, D. J.; ZAMBOLIM, L.; VIEIRA, R. A.; OLIVEIRA, R. R. Progress of Asian soybean rust and airborne urediniospores of Phakopsora pachyrhizi in southern Brazil.

Summa Phytopathologica, Botucatu, v. 38, n. 4, p. 280-287. 2012.

OLIVEIRA, M.; RIBEIRO, H.; DELGADO, J. L. The effects of meteorological factors on airborne fungal spore concentration in two areas differing in urbanisation level. International Journal of Biometeorology, Berlin, v. 53, n. 1, p. 61-73. 2009a. https://doi.org/10.1007/s00484-008-0191-2

OLIVEIRA, M.; GUERNER-MOREIRA, J.; MESQUITA, M.; ABREU, I. Important phytopathogenic airborne fungal spores in a rural area: incidence of Botrytis cinerea and Oidium spp. Annals of Agricultural and Environmental Medicine, Lublin, v. 16, n. 2, p. 197-204. 2009 b.

PEEL, R.; ORBY, P. V.; SKJOTH, C. A. Seasonal variation in diurnal atmospheric grass pollen concentration profiles. Biogeosciences, v. 11, p. 821-832. 2014. https://doi.org/10.5194/bg-11-821-2014

RIEUX A.; SOUBEYRAND, S., BONNOT, F.; KLEIN, E. K.; NGANDO, J. E. Long-Distance WindDispersal of Spores in a Fungal Plant Pathogen: Estimation of Anisotropic Dispersal Kernels from an Extensive Field Experiment. Plos One, San Francisco, v. 9, n. 8, e103225. 2014.

https://doi.org/10.1371/journal.pone.0103225

ROSA, C. R. E.; SPEHAR, C. R.; LIU, J. Q. Asian Soybean Rust Resistance: An Overview. Journal of Plant Pathology and Microbiology, v. 6, n 9, p. 1-9. 307. 2015.

SCHUH, W. Influence of interrupted dew periods, relative humidity, and light on disease severity and latent infections caused by Cercospora kikuchii on soybean. Phytopathology, St. Paul, v. 83, n. 1, p. 109-113. 1993.

VUORINEN, P.; HELANDER, M. Variation in airborne urediniospore concentration of Melampsoridium betulinum. Aerobiologia, v. 11, p. 259-264. 1995. https://doi.org/10.1007/BF02447206

YÁÑEZ-LÓPEZ, R.; HERNÁNDEZ-ZUL, M. I.; QUIJANO-CARRANZA, J. A.; TERÁN-VARGAS, A. P., PÉREZ-; L., DÍAZ-PADILLA, G.; RICO-GARCÍA, E. Potential distribution zones for soybean rust (Phakopsora pachyrhizi) in Mexico. Ecosistemas y Recursos Agropecuarios, Villahermosa, v. 2, n. 6, p. 291 302. 2015.

YOUNG, H. M.; MAROIS, J. J.; WRIGHT, D. L.; NARVÁEZ, D. F.; O’BRIEN, G. K. Epidemiology of soybean rust in soybean sentinel plots in Florida. Plant Disease, St. Paul, v. 95, n. 6, p. 744-750. 2011.

YORINORI, J. T.; PAIVA, W. M.; FREDERICK, R. D.; COSTAMILAN, L. M.; BERTAGNOLLI, P. F.; GODOY, D. V.; NUNES, J. J. Epidemics of soybean rust (Phakopsora pachyrhizi) in Brazil and Paraguay from 2001 to 2003. Plant Disease, St. Paul, v. 89, n. 6, p. 675-677. 2005.

WAKEHAM, A. J.; KENNEDY, R. Risk assessment methods for the ringspot pathogen Mycosphaerella brassicicola in vegetable Brassica crops. Plant Disease, St. Paul, v. 94, n. 7, p. 851-859. 2010.

WEST, J. S.; KIMBER, R. B. E. Innovations in air sampling to detect plant pathogens. Annals of Applied Biology, Oxford, v. 166, n. 1, 4-17. 2015. https://doi.org/10.1111/aab.12191

WEST, J. S.; CANNING, G. G. M.; PERRYMAN, S. A.; KING, K. Novel Technologies for the detection of Fusarium head blight disease and airborne inoculum. Tropical Plant Pathology, Viçosa, v. 42, n. 3, p. 203209. 2017 